\title{
Analysis on the Mechanism of Information Technology in Promoting the Development of Sports Industry
}

\author{
Yuan Zhang \\ Northwest University, Xian 710069, China
}

Keyword: Internet information technology; Sport industry; Physical education; Analysis

\begin{abstract}
Purpose: Developing sports spirit and culture is the eternal goal of human development. At present, the domestic sports industry chain has been formed, but there are still many problems in the process of handling and convergence. The level of public service is relatively primary, there are some defects in the development of sports products. These problems are due to poor communication; information feedback is not timely. With the rapid development of information technology, the application of information technology to the sports industry is an inevitable trend. Whether it is to change people's awareness of consumption or improve the scale of the sports industry, are helpful to the development of the industry. These methods need to rely on the Internet and computer technology to complete.
\end{abstract}

Results: It is clear that the modern information technology plays a positive role in the development of sports industry.

\section{Overview of Information Technology}

Concept. Information technology, also known as information and communication technology, is abbreviated to IT. Information technology is a general term for managing and processing information. The core of information technology is made up of four kinds of technologies, which are sensor technology, communication technology, control technology, computer and intelligent technology. Broadly speaking, it emphasizes the relationship between human beings and information technology. The development of human organ function is the goal of all kinds of skills. There is a close relationship between information technology and the development of the internet. The most important application of information technology is the development of computer software and hardware, network communication technology and so on. Human development cannot do without the information technology development progress, so all areas are beginning to have full use of information technology, and the characteristics of various fields, to optimize the information technology to improve the dissemination of information.

Characteristic. There is a close relation of information technology and the Internet, in the research of computer and network technology, the relevant professional puts forward five development trends, namely digital and network, multimedia, intelligence, virtualization. This is the main feature of information technology. Information technology itself has the following characteristics:

Super high input

The achievements and results of the current information technology are the result of the preinvestment. Due to the high technical characteristics of information technology, it is necessary to invest a lot of money and talents. This part of the investment directly affects the final effect of information technology.

Super high drive

Full integration of information technology and the internet. In the current Internet era, the development of information technology is bound to promote the progress of various industries. Therefore, it has a strong driving force.

Super high permeability 
Information technology is based on people's skills, so it will permeate all areas of people's life, work and study. At the same time, the progress of information technology will also have a positive role in promoting the national economy.

Super high multiplication

High multiplication is one of the characteristics of information technology. This is also a lack of other technologies. The application of information technology in the production process, through the lower cost of output, you can get higher output value of the product, in order to obtain more profits.

Super high innovation

It is often said that the computer has changed our life, and the computer is just a breakthrough in information technology. In addition, the application of semiconductor, satellite communication and optical fiber are the innovation of information technology.

\section{How is the Development of Sports Industry under the Influence of Information Technology}

Structural Optimization of Sports Industry. Sports industry is one of the most important application fields of information technology, and it is beneficial to the development of sports spirit to build a perfect industrial structure. The informatization construction of sports industry is the individual behaviors and collective behaviors together, improve the various industrial processes, respect the autonomy of different sports organizations have independent, facing the market of sports industry process optimization. Allocate human resources and material resources between departments through advanced information technology. At present, the structure of the sports industry in China is still relatively elementary, and the content of people's consumption is based on the sports goods, accounting for 79\%. This is compared with the United States there are still some differences between 32\%, see Fig. 2-1. Under the influence of information technology, people have a new understanding of the sports industry, such as the current sports fitness and entertainment projects just need to increase, the structure of the sports industry will also change. Therefore, it is necessary to develop the information technology to improve people's cognition and meet the needs of the market.

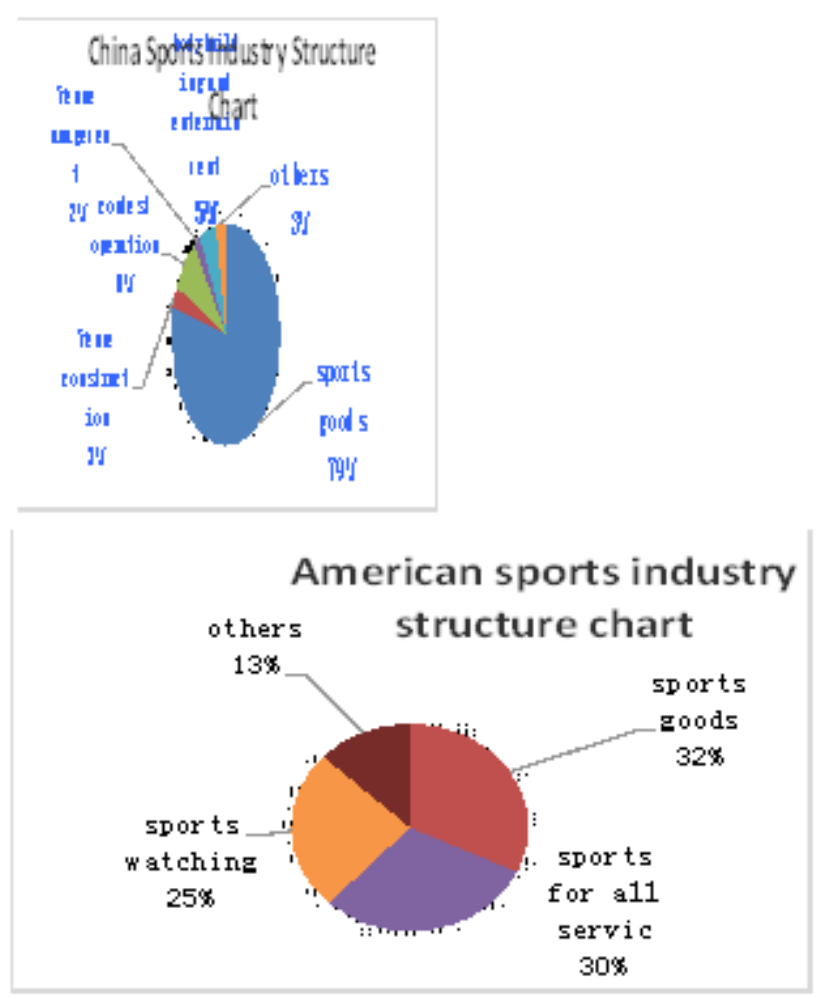

Figure 1. Comparison of the current Chinese and American sports industry structure 
Changing Consumption Habits of Sports Products. Before, people are not perfect the concept of sports consumption of the product, but in the development of information technology era, people through the Internet, television, media and other forms, to understand more and more sports knowledge, but also the beginning of a consumer awareness of sports products. Now people can buy sports products through the Internet, watching the world sports events on TV, which is the change of consumption habits brought by information technology. As far as sports industry is concerned, there are two kinds of consumption: appreciation and participation. These two aspects are essential, but also rely on each other. Sports venues and facilities is clearly the most important media, signed a transformation from real estate economic principles are stadiums and sports, in order to meet the current national sport craze. When the Internet meets the sports industry, the collision of a different kind of spark. See Table 1.

Table 1 China "INTERNET + SPORTS INDUSTRY" reflects

\begin{tabular}{|l|l|l|}
\hline & Sports fitness & Competitive sports \\
\hline Watch & KEEP & Youku、Tudou \\
\hline Join & Letv football & China lottery \\
\hline $\begin{array}{l}\text { Social } \\
\text { contact }\end{array}$ & MI Sports & QQ、Baidu Forum \\
\hline Purchase & Union Sports & Taobao、Damai \\
\hline Data tracing & Codoon & cubegoal \\
\hline
\end{tabular}

Improve the Operation Mode of Sports Industry. Depending on the enterprise itself, the sports industry chain cannot be completed very well, and all the enterprises cooperate with each other to form a complete industrial chain. Through the cooperation to form a powerful sports product production network, from the base of sporting goods to sports services, to meet the needs of users. The Internet to play the role of the connection, the different enterprise products linked together, the staff will be linked together within the enterprise to form a virtual service network. The location of each network needs to respond to the needs of users in a timely manner, through information technology to achieve the ultimate service. Users through the computer network to achieve the consumption of sports products, and then to evaluate consumer products, to promote the desire of other users.

Reduce the Cost of Sports Industry. Whether it is the promotion of the economy or the rise of the Internet, people began to pay attention to the importance of sports. With the development of the situation, the gross domestic product of the sports industry shows a rising trend. In 2011 GDP reached 244 billion 263 million yuan, and this value is more than two times in 2007, more than 126 billion 533 million yuan. Sports industry has created tangible benefits for the increase of national economy. Sports industry development, the relevant practitioners also have a certain increase, but its growth rate is relatively stable. The reason for this phenomenon is inseparable from the current enterprise information technology management. The mechanical work to the computer, more practitioners are customized services or planning and other creative work, improve the efficiency of the use of personnel, reduce the cost of industrial output. 


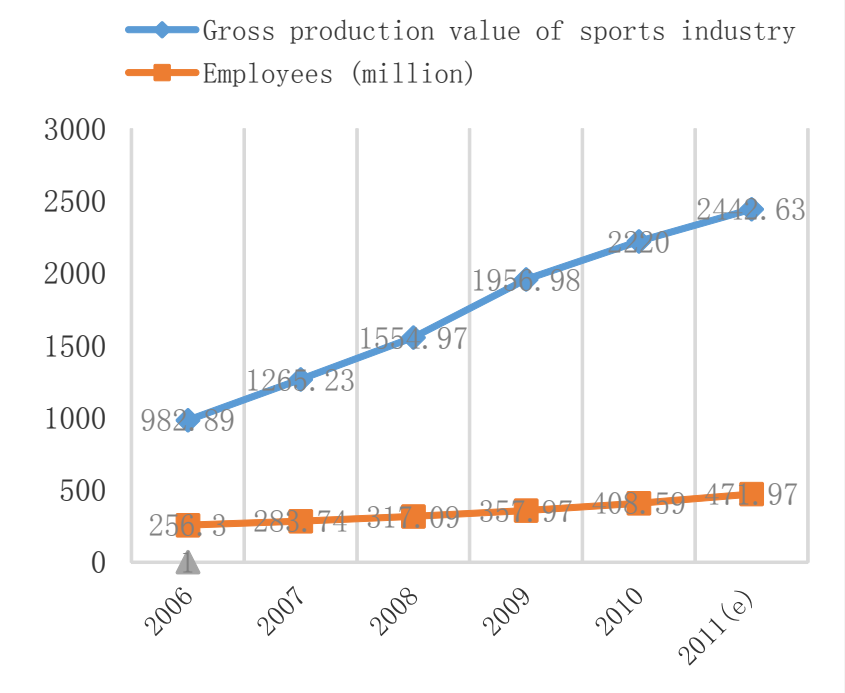

Figure 2. Sports industry output value and employment trends

\section{Competitive Sports to Healthy China, Information Technology to Promote Development}

Information Technology Improve People's Awareness of Participating in Sports.Sports industry is a complete industrial chain, as the public is not fully understanding of the sports industry. Based on information technology, strengthen propaganda, and the use of WeChat, micro-blog, forums and other network media, penetration of the influence of sports event TV broadcast, increase sports entertainment section, sports health communication idea, improve people's interest in sports, let people independently to join sports activities in the atmosphere, the potential of different age some of the sports consumption, so as to provide lasting power for the economic growth of the country.

The Development of Information Technology and the State Government Support.The development of sports industry requires a large amount of capital, manpower and material resources, this part of the enterprise itself is not enough. In the current popular sports entertainment activities in terms of the number of venues and facilities are not complete, functional difference and other practical factors, will affect the enthusiasm of sports, in addition to the stadium itself for the perfect function, but also the needs of local government support. As for China, the development of the sports industry is a huge boost to economic income, so the information technology in the sports industry application, needs a scientific implementation plan, in accordance with the corresponding proportion of support.

The Information Technology Innovation of the Sports Industry Sales.Traditional sports industry sales to the public's influence is small, mostly for one-time consumption, and with the help of information technology, by increasing the relevance of consumer products, help to promote the awareness of multiple consumption. According to the information technology to control the market, understand the supply and demand for sports products production, ensure product output. For different ages, providing sports products of personal choice, now many young people often go out to travel, and challenging tourism projects like bungee jumping, rock climbing, rafting and skiing are very interested in the establishment of the sports industry, the corresponding project can be very good to meet the needs of people.

Using Information Technology to Build Sports Industry Bridge.Let everyone who has a sense of sports can join the ranks of sports. In addition, the use of information technology to optimize the production chain, reduce production costs, improve product quality, promote consumption.

The sports industry is a whole, each link is an indispensable part, each part of the enterprise is not independent, only to combine together in order to gain more market share. The sports industry is 
not perfect in our country, many foreign brands compared, there is still a large gap, in this premise, each enterprise should jointly complete each link of the sports industry, only complementary advantages can be achieved greater success.

Conclusion: The arrival of the era of information technology, the Chinese sports to complete the transition from competitive sports to healthy life. People through the network, television, media and other forms of communication, to learn more and more knowledge of sports, in order to carry out physical health, sports products have a sense of consumption. People through the network, television, media and other forms of communication, to learn more and more knowledge of sports, in order to carry out physical health, sports products have a sense of consumption. For the current China sports industry, information technology is the trend of the times, break up the whole into parts, increase the relevance of sports products, the promotion of two people's desire for consumption, improve product output. From the consumer, the market was the world. Therefore, in the use of the Internet and computer, the sports industry accurately grasps the market pulse to lead the industry to get permanent development.

\section{References}

[1] Chao-Sen Wu,Cheng-Jong Lee,Li-Fen Tsai. Influence of creativity and knowledge sharing on performance[J]. Journal of Technology Management in China, 2012,7(1):64-77

[2] Zekeriya GÖKTAȘ. THE SELF- CONF İENCE LEVELS OF PHYSICAL EDUCATION AND SPORT STUDENTS TOWARDS INFORMATION AND COMMUNICATION TECHNOLOGIES(ICT)[J]. Beden Egitimi ve Spor Bilimleri Dergisi,2011,5:50

[3] C.P., Effective integration of ICT in Singapore schools: pedagogical and policy implications. Education Technology, Research and Development, 55(1), 83-116, 2007.

[4] McGrail, E., Teachers, technology and change: English teachers' perspectives.Journal of Technology and Teacher Education, 13(1), 5-24,2005.

[5] Bandura, A., Social foundations of thought and action. Englewood Cliffs, NJ: Prentice-Hall. 1986.

[6] Cohen, D.K., ve Ball, D.L.,Policy and practice: An overview. Educational Evaluation and Policy Analysis, 12(3), 347-353, 1990.

[7] Deubel, P., An investigation of behaviorist and cognitive approaches to instructionaldesign. Journal of Educational Multimedia and Hypermedia, 12(1), 63-90.2003.

[8] Christanse, R., Effects of technology integration education on the attitudes of teachers and students. Journal of Research on Technology in Education, 34(4) 411-434, 2002.

[9] Collier, K. G., Paula, F.J. \& Goff, R.J., Colleges of Education LearningProgrammes: A proposal (Working Paper No.5). Washington, DC: Commission on Instructional Technology, 1971.

[10] Crowther, M. S., Keller, C. C. \& Waddoups, G. L., Improving the quality and effectiveness of computer-mediated instruction through usability evaluations. British Journal of Educational Technology, 35(3), 289-303, 2004.

[11]Dincer B., Özaslan, M. ve Kavasoğlu., T., İllerin ve bölgelerin sosyo ekonomik gelişmişlik sıralaması araştırması. Ankara: Devlet Planlama Teskilatı Yay., 2671,2003.

[12]Hopson, M.H., Simms, R.L., and Knezek, G.A., Using a technologically enriched environment to improve higher-order thinking skills. Journal of Research on Technology in Education, 34 (2), 109-119,2002. 